УДК 657.1:37.07

JEL classification: M48, H52, 122

\section{Світлана СИСюК}

кандидат економічних наук, дочент, доцент кафедри обліку і оподаткування, Західноукраїнський національний університет, Україна

ORCID ID: 0000-0001-6697-1289

Researcher ID: H-2909-2017

\section{Надія ХОРУНЖАК}

доктор економічних наук, професор, профресор кафедри обліку і оподаткування, Західноукраїнський національний університет, Україна

ORCID ID: 0000-0001-7434-5456

Researcher ID: H-3779-2017

(c) Світлана Сисюк, Надія Хорунжак, 2021

Отримано: 05.02.2021 p

Прорецензовано: $12.02 .2021 \mathrm{p}$.

Рекомендовано до друку: 24.02.2021 p.

Опубліковано: 24.02.2021 p.

Ця стаття розповсюджується на умовах ліцензії Creative Commons AttributionNonCommercial 4. 0, яка дозволяє необмежене повторне використання, розповсюдження та відтворення на будь-якому носії, за умови правильного цитування оригінальної роботи.
Світлана Сисюк (Україна)

Надія Хорунжак (Україна)

\section{APXITEKTOHIKA MEXAHIЗMY ФІНАНСУВАННЯ ОСВІТИ В СУЧАСНИХ УМОВАХ І ШЛЯХИ РІШЕННЯ ПРОБЛЕМИ ЙОГО АЛЬТЕРНАТИВ В ОБЛІКУ}

\section{АНОТАЦІЯ}

Вступ. Новий механізм фінансового забезпечення, визначений відповідними Законами України, запровадження національних стандартів обліку та плану рахунків для державного сектору, децентралізація та інші трансформаційні процеси суттєво вплинули як на систему фінансування в сфері освіти, так і на організацію та методику бухгалтерського обліку. Але прагнення до удосконалення цих систем наразі не повною мірою відповідає існуючим реаліям і запитам, в тому числі сучасного менеджменту.

Метою статті $\epsilon$ дослідження механізму формування й використання фінансового забезпечення навчальних закладів - коледжів в контексті організаційних і облікових моментів, а також розробка пропозицій з їх уточнення та вдосконалення (в т. ч. в обліковій політиці).

Методи (методологія). У досліджені застосовані загальнонаукові методи, зокрема теоретичного узагальнення та аналізу - для виявлення специфіки здійснення фінансування освітніх закладів в умовах трансформаційних змін, моделювання - з ціллю формування ефективного механізму фінансування і розробки облікової політики в частині регулювання наявних альтернатив щодо відображення його надходження в обліку.

Результати. За результатами проведених досліджень чинних законодавчих приписів встановлено, що фінансове забезпечення державних закладів фахової передвищої освіти провадиться за рахунок коштів державного (або місцевого) бюджету на умовах державного (або регіонального) замовлення на оплату послуг з підготовки фахових молодших бакалаврів. Визначено можливість фінансування за рахунок інших джерел, які не заборонені законодавством, 3 обов'язковим дотриманням принципів цільового та ефективного використання коштів, публічності та прозорості у прийнятті рішень. Побудовано модель фінансового забезпечення закладів освіти 3 урахуванням додаткових джерел фінансування, які розподілено на зовнішні та внутрішні, а також розроблено рекомендації щодо розробки положень облікової політики з питань їх відображення в обліку.

Сисюк С., Хорунжак Н. Архітектоніка механізму фінансування освіти в сучасних умовах і шляхи рішення проблеми його альтернатив в обліку. Економічний аналіз. 2021. Том 31. № 1. С. 186-195.

DOI: https://doi.org/10.35774/econa2021.01.186

Ключові слова: державний сектор; сфера освіти; фінансове забезпечення; механізм фінансування; бухгалтерський облік; облікова політика; модель; удосконалення. 
UDC 657.1:37.07

JEL classification: M48, H52, 122

\section{Svitlana SYSIUK}

PhD in Economics,

Associate Professor,

Department Accounting and Taxation,

West Ukrainian National University, Ukraine

ORCID ID: 0000-0001-6697-1289

Researcher ID: H-2909-2017

\section{Nadiya KHORUNZHAK}

Doctor of Economy Science,

Professor,

Department Accounting and Taxation,

West Ukrainian National University, Ukraine ORCID ID: 0000-0001-7434-5456

Researcher ID: H-3779-2017

(C) Svitlana Sysiuk, Nadiya Khorunzhak, 2021

Received: 05.02.2021

Revised: 12.02.2021

Accepted: 24.02.2021

Online publication date: 24.02 .2021

\section{(c) (1) (8)}

This is an Open Access article, distributed under the terms of the Creative Commons AttributionNonCommercial 4. 0 license, which permits unrestricted re-use, distribution, and reproduction in any medium, provided the original work is properly cited.
Svitlana Sysiuk (Ukraine) Nadiya Khorunzhak (Ukraine)

\section{ARCHITECTONICS OF THE MECHANISM OF EDUCATIONAL FINANCING IN MODERN CONDITIONS AND WAYS OF SOLVING THE PROBLEM OF ITS ALTERNATIVE IN ACCOUNTING}

\section{ABSTRACT}

Introduction. The new financial support mechanism defined by the relevant laws of Ukraine, the introduction of national accounting standards and a chart of accounts for the public sector, decentralization and other transformation processes have significantly influenced both the education financing system and the organization and methodology of accounting. But the desire to improve these systems currently does not fully correspond to the existing realities and requirements, including modern management.

The purpose of the article is to study the mechanism for the formation and use of financial support for educational institutions - colleges in the context of organizational and accounting aspects, as well as the development of proposals for their clarification and improvement (including accounting policy).

Methods (technique). The study uses general scientific methods, including theoretical generalization and analysis - to identify the specifics of financing educational institutions in the context of transformational changes, modeling - in order to form an effective financing mechanism and develop accounting policies to regulate alternatives that exist in the financial provision of educational institutions.

Results. According to the results of the study of the current legislation, it was established that financial support of state institutions of professional higher education is carried out at the expense of the state (or local) budget on the basis of a state (or regional) order for payment for training services. There is also the possibility of financing from other sources not prohibited by law, with the obligatory observance of the principles of targeted and effective use of funds, publicity and transparency of decision-making. Based on the results of the research, a model of financial support for educational institutions was built, taking into account additional sources of funding, which are divided into external and internal, and also justified recommendations for the development of accounting policies for their reflection in accounting.

Sysiuk, S., \& Khorunzhak, N. (2021). Architectonics of the mechanism of educational financing in modern conditions and ways of solving the problem of its alternative in accounting. Economic analysis, 31 (1), 186-195.

DOI: https://doi.org/10.35774/econa2021.01.186

Keywords: public sector; the sphere of education; financial support; financing mechanism; Accounting; accounting policy; model; improvement. 
www.econa.org.ua

\section{Вступ}

Освіта - це процес і результат засвоєння особистістю певної системи наукових знань, практичних умінь і навичок і пов'язаного з ними того чи іншого рівня розвитку ії розумовопізнавальної і творчої діяльності; це спеціальна сфера соціального життя, унікальна система, своєрідний соціокультурний феномен, який сприяє нагромадженню знань, умінь і навичок, інтелектуальному розвитку людини. 3 огляду на це важливим стратегічним питанням, від вирішення якого повною мірою залежить функціонування закладів освіти $€$ організація їх фінансового забезпечення та його обліку. Будучи основним інформаційним джерелом (базою) для управління останній формує необхідну для прийняття рішень інформацію.

Удосконалення механізму фінансування та самої інформаційної бази управління ним важливий напрям забезпечення зростання ефективності діяльності суб'єктів державного сектору, якими $€$ заклади освіти. В державному секторі, у якому впродовж останніх десятиліть існує тенденція до недофінансування та браку бюджетних коштів, питання оптимізації фінансування та його використання надзвичайно актуальне.

Новий механізм фінансового забезпечення, визначений відповідними Законами України, запровадження національних стандартів обліку та плану рахунків для державного сектору, децентралізація та інші трансформаційні процеси суттєво вплинули як на систему фінансування в сфері освіти, так і на організацію та методику бухгалтерського обліку. Але прагнення до удосконалення цих систем наразі не повною мірою відповідає існуючим реаліям і запитам, в тому числі сучасного менеджменту.

Особливо потерпають від браку чітких та детальних рекомендацій щодо ведення обліку такі специфічні суб'єкти державного сектору, як заклади фахової передвищої освіти. Це пов'язано 3 наявністю низки особливостей і проблем, які мають місце в їх діяльності в питаннях отримання бюджетних асигнувань і інших джерел надходжень.

Питання фінансового забезпечення освіти і його обліку в останні роки досліджується багатьма вченими і практиками. Серед них слід назвати таких авторів як І. Д. Бенько [1], О. В. Баранецька [2], Я. Г. Бучковська [2], 3. С. Варналій [4], В. І. Глухова [6], Григанська С. В. [7], Д. М. Загірняк [8], О. В. Красільник [4], О.В.Люта [12], Г. Л. Норд [11], Н. Г. Пігуль [12], Н. О. Руденко [11], л. П. Хмелевська [5] та інших.

Тематика досліджень охоплює різноманітні питання, пов'язані з діяльністю закладів освіти в сучасних умовах в частині отримання та витрачання ними фінансових ресурсів, які в державному секторі частіше ідентифікуються як фінансове забезпечення, фінансування або асигнування 3 бюджету. Значною мірою вживання цих понять пояснюється організаційним статусом освітнього закладу.

Ознака державної форми власності може визначати приналежність або до державних підприємств або надавати статус бюджетних для таких установ. Специфічними ознаками бюджетних установ І. О. Лукашова та К. О. Полозюк [14] називають: правовий статус, правовий режим майна, форми реалізації права власності. Автори наголошують на тому, що бюджетна установа може бути як самостійною юридичною особою, так i відокремленим підрозділом. Розпоряджатися державним майном (і коштами) установи можуть на рівні головного розпорядника коштів, розпорядників нижчого рівня. Колектив авторів на чолі 3 3. С. Варналій зазначають, що в Україні типовою $€$ змішана система фінансування, яка передбачає поєднання державного і приватного фінансування [5, с. 23].

В умовах ресурсного дефіциту в сфері освіти та сучасних обмежень при здійсненні діяльності, зокрема карантинних, важливо максимально оптимізувати іiі, щоб бути не лише конкурентоздатними на ринку, а й мати економічні преференції та вигоди в нестабільній глобальній економіці.

У зв'язку з цим проблематика удосконалення механізму фінансування як найважливішого ресурсу освітніх закладів та його обліку і їх спрямування на досягнення кращих результатів діяльності та раціонального використання бюджетних коштів актуальна й, одночасно, ускладнена через відсутність в більшості українських суб'єктів державного сектору якісної та ефективної практики обліку. В останні роки ця ситуація суттєво покращується, але є потреба у посиленні галузевої спрямованості та розробці методичних рекомендацій більш вузького спрямування, ніж $\epsilon$ у наших національних стандартах. Тому дослідження присвячені цій актуальній проблемі повинні розвиватися як в теоретичній, так і в практичній площині. Адже незважаючи на високий рівень репрезентації окреслених проблем у фаховій літературі, залишаються невирішеними ряд важливих положень, пов'язаних, зокрема, з механізмом формування та використання фінансового забезпечення закладів фахової перед вищої освіти, модель і процес їх фінансового забезпечення в сучасних умовах, а також те, як вони позначаються на системі обліку.

\section{Мета статті}

Метою статті $\epsilon$ дослідження механізму формування й використання фінансового 
www.econa.org.ua

забезпечення закладів фахової перед вищої в контексті організаційних і облікових моментів, а також розробка пропозицій 3 їх уточнення та вдосконалення (в т. ч. в обліковій політиці).

\section{Виклад основного матеріалу дослідження}

Питання формування та використання фінансових ресурсів навчальних закладів лежить в площині бюджетного законодавства, основним нормативно-правовим актом, що визначає теоретичні засади такого процесу $€$ Бюджетний кодекс України. Відповідно до Бюджетного кодексу [3], визначено основні складові формування та використання фінансових ресурсів бюджетними установами, що в повному обсязі характеризує сутність даного процесу. Слід зазначити, що бюджет та відповідно і кошторис державних закладів фахової перед вищої освіти поділяється на загальний та спеціальний фонди, перший - це виключно фінансування з державного бюджету, а спеціальний фонд - надходження за послуги в частині освітньої, наукової, науково-технічної, інноваційної та/або методичної діяльності та інші надходження. Механізм формування та використання фінансових ресурсів навчальних закладів - коледжів відповідно до чинного бюджетного законодавства наведено на рис.1.

Як видно з рис. 1, формування та використання фінансових ресурсів закладів освіти строго регламентується бюджетним законодавством, в тому числі і по власних коштах. Наведений механізм формування та використання фінансових ресурсів закладів фахової передвищої освіти відповідно до бюджетного законодавства відображає напрями надходження, що формують загальний та спеціальний фонди, а також можливі напрями використання фінансових ресурсів по кожному надходженню. Доцільно під категорією формування фінансового забезпечення коледжів, 3 огляду на їх функціональні особливості, розуміти процес надходження доходів до спеціального та загального фондів задля забезпечення його функціонування та провадження освітньої, науковотехнічної, інноваційної та/або методичної діяльності.

Натомість, під категорією використання фінансових ресурсів навчальних закладів розуміти процес витрачання сформованих фінансових ресурсів закладами освіти за напрямами, визначеними законодавством 3 метою забезпечення його функціонування та провадження освітньої, науково-технічної, інноваційної та/або методичної діяльності.

Українські вченні Норд Г. та Руденко Н. [11, с. 62-63] визначають наступні «основні проблеми, з якими стикається в своїй господарській діяльності вищі навчальні заклади, в тому числі і коледжі, а came:
- зменшення маневрування власними коштами (кошти спеціального фонду включені до складу Державного бюджету України);

- повна залежність стабільності надходжень коштів загального фонду від політичної та економічної ситуації в країн;

- неможливість точного прогнозування майбутніх потреб у фінансуванні через регламентовані терміни бюджетного процесу;

- неспівпадання реального рівня фінансової незалежності із задекларованими намірами;

- значна розпорошеність у підпорядкуванні ДВН3, що зменшує можливості управління та контролю їх діяльності єдиним розпорядником».

Введення в дію Закону України «Про вищу освіту» у 2014 році, де вперше було порушено та визначено питання автономії університетів, поклав початок розширенню можливостей вищих навчальних закладів. Згідно закону [15], «автономія вищого навчального закладу визначається, як самостійність, незалежність і відповідальність вищого навчального закладу у прийнятті рішень стосовно розвитку академічних свобод, організації освітнього процесу, наукових досліджень, внутрішнього управління, економічної та іншої діяльності, самостійного добору і розстановки кадрів у межах, встановлених законом». Аналогічно такі ж підходи до автономії і простежуються у Законі «Про фахову передвищу освіту» [16].

На думку Н. Г. Пігуль та О. В. Лютої [12, с. 101], «відокремлення коштів за спеціальним фондом від коштів Державного бюджету, а також переведення ïx $з$ обслуговування Держказначейства до інших банківських установ збільшить ефективність господарської діяльності, а також підвищить їх фінансову автономію. Запровадження часткової автономії дВН3 підвищить ефективність їх функціонування. Це надасть їм змогу не тільки самостійно залучати додаткові фінансові ресурси, але й витрачати їх, виходячи із власних потреб, що може стати стимулом для їхнього розвитку і, навіть, виникнення конкуренції за право реалізовувати власні освітні послуги на ринку».

3 точки зору С. В. Григанської [7], питання підвищення ефективності формування та використання фінансових ресурсів державних вищих навчальних закладів лежить в площині необхідності «заміни попереднього витратного механізму виділення коштів з Державного бюджету на цільовий; надання коштів 3 державного бюджету на основі диференційованого підходу до потреб кожного ДВНЗ; перехід від централізованої структури розподілу бюджетних коштів до децентралізованої. 


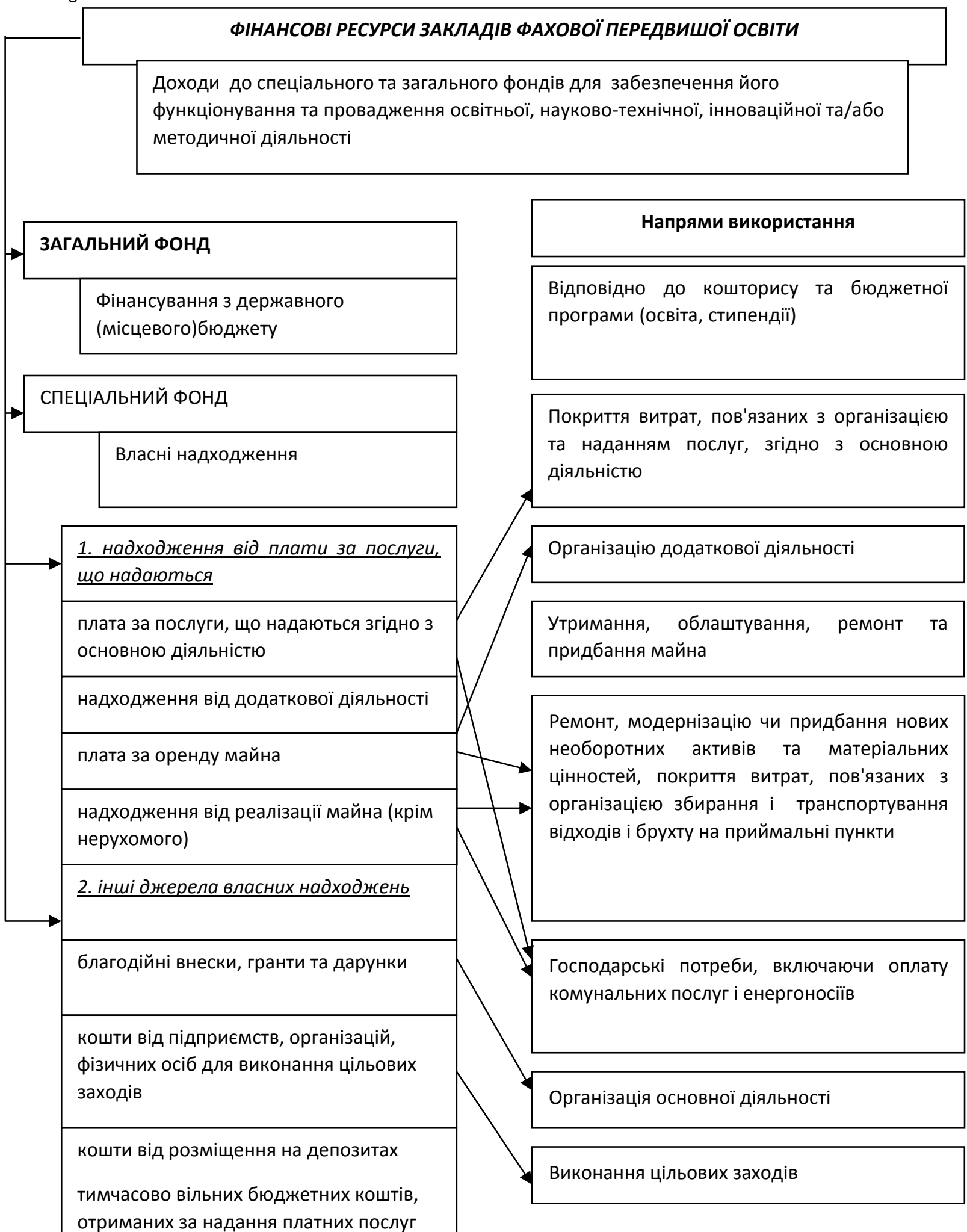

Рис. 1. Механізм формування та використання фінансового забезпечення закладів фахової перед вищої освіти відповідно до бюджетного законодавства

Примітка. Розроблено авторами на основі [3].

Можливими варіантами переходу на багаторівневе фінансування $€$ розподіл статей фінансування та розподіл фінансування за напрямками підготовки». Оскільки фінансування освіти, у тому числі і фахових коледжів передвищої освіти відбувається у розрізі бюджетних програм, то виникає необхідність визначення результативних показників. Результативними показниками оцінки ефективності бюджетних програм фінансування можуть виступати: 
www.econa.org.ua

- кількість штатних одиниць, підрозділів, обладнання;

- кількість студентів, підготовлених молодших бакалаврів;

- кількість студентів на одного викладача, вартість підготовки одного студента;

- підвищення якості підготовки з минулим навчальним роком.

При цьому застосування таких результативних показників спрямоване на моніторинг, аналіз та контроль за цільовим та ефективним використанням бюджетних коштів навчальними закладами лише за конкретною бюджетною програмою. Натомість не здійснюється оцінка та аналіз загальної ефективності діяльності державних навчальних закладів та її складових [10, с. 59].

Понад 90\% державних інвестицій в освіту спрямовується на поточні видатки, 3 них переважна частина - на виплату заробітної плати та нарахування на неї, які зростають в наслідок інфляційних процесів. Така структура видатків не забезпечує достатньої можливості для перерозподілу ресурсів на користь тих, які безпосередньо визначають якість освітніх послуг (підвищення кваліфікації освітян, розширення та оновлення ресурсної бази навчальних закладів, впровадження новітніх технологій) та сприяють вдосконаленню освітньої інфраструктури [9, с. 81]. Що стосується діяльності коледжу, як бюджетної установи, яка приносить дохід, то вона може здійснюватися відповідно до встановленого державою порядку надання платних послуг та відноситься до видів діяльності, передбачених установчими документами установи (статутом, положенням). Ціна на платні послуги повинна встановлюватися органом, що здійснює функції і повноваження засновника. Прибуток, отриманий в результаті такої діяльності, спрямовується на цілі діяльності установи.

Схематично модель фінансового забезпечення діяльності закладів фахової перед вищої освіти в Україні представлено на рис. 2.

Таким чином, на нашу думку для покращення фінансового стану навчальних закладів зростає роль власних джерел фінансування в забезпеченні їхнього функціонування. Кошти спеціального фонду $€$ результатом самостійної фінансово-господарської діяльності закладу освіти. Основними джерелами таких коштів, як свідчить рис. 2, можуть бути кошти за надання платних послуг (відповідно до законодавчо визначеного переліку) та спонсорські кошти.

Але сучасна система фінансового забезпечення коледжів потребує суттєвих заходів задля її удосконалення. Результатом таких заходів має стати посилення фінансової стійкості навчальних закладів, що передбачає такий стан їх фінансових ресурсів, за якого спостерігається постійне та стабільне надходження коштів, раціональне і ефективне їх використання, вміння залучати вищими навчальними закладами фінансові ресурси самостійно, відповідно до чинного законодавства.

Існує певна специфіка фінансування закладів передвищої освіти (які не знаходяться в структурі вищих закладів освіти). Щодо цього, зокрема слід врахувати особливості програмано-цільового методу.

Застосування цього методу державними освітніми закладами дозволяє більш ефективно використовувати наявні фінансові ресурси, зміцнити матеріальну, організаційну та фінансову самостійність. Своєю чергою це забезпечує правильний і обґрунтований розподіл бюджетних коштів на виконання пріоритетних завдань освітнього закладу. Використання програмноцільового методу показує взаємозалежність між коштами та результатом. Цей метод реалізується через бюджетну програму.

Бюджетною програмою є система дій, яка має на меті досягнути відповідні завдання, цілі та результати, формулювання та виконання яких покладено на розпорядника бюджетних коштів відповідно до його визначених функцій [3; 13].

Згідно бюджетної програми, їі виконавець (заклад фахової перед вищої освіти) отримує кошти лише у відповідності до встановлених показників реалізації програми та визначення ії ефективності по завершенню окремих етапів. Зазвичай бюджетна програма передбачає найбільш якісне та ефективне надання послуг, що припадають на одиницю виділених коштів 3 бюджету. Мета бюджетної програми має бути чітко визначеною, реальною та досяжною для виконання.

Основними завданнями бюджетної програми є:

- визначені цілі, які потрібно досягти при умові виконання бюджетної програми;

- оцінка виконання програми за допомогою результативних показників;

- відповідність пріоритетам державної політики у відповідних напрямках. Окрім тога заклади фахової перед вищої освіти можуть отримувати власні надходження, які враховуються у доходах спеціального фонду.

у зв'язку з реформуванням професійної освіти коледжі з 2018 року переведені на фінансування 3 обласних бюджетів, окрім коледжів, які знаходяться у структурі 3ВО. Також коледжам у межах чинного законодавство дозволено надавати платні послуги та одержувати у своє розпорядження додаткові фінансові ресурси. 


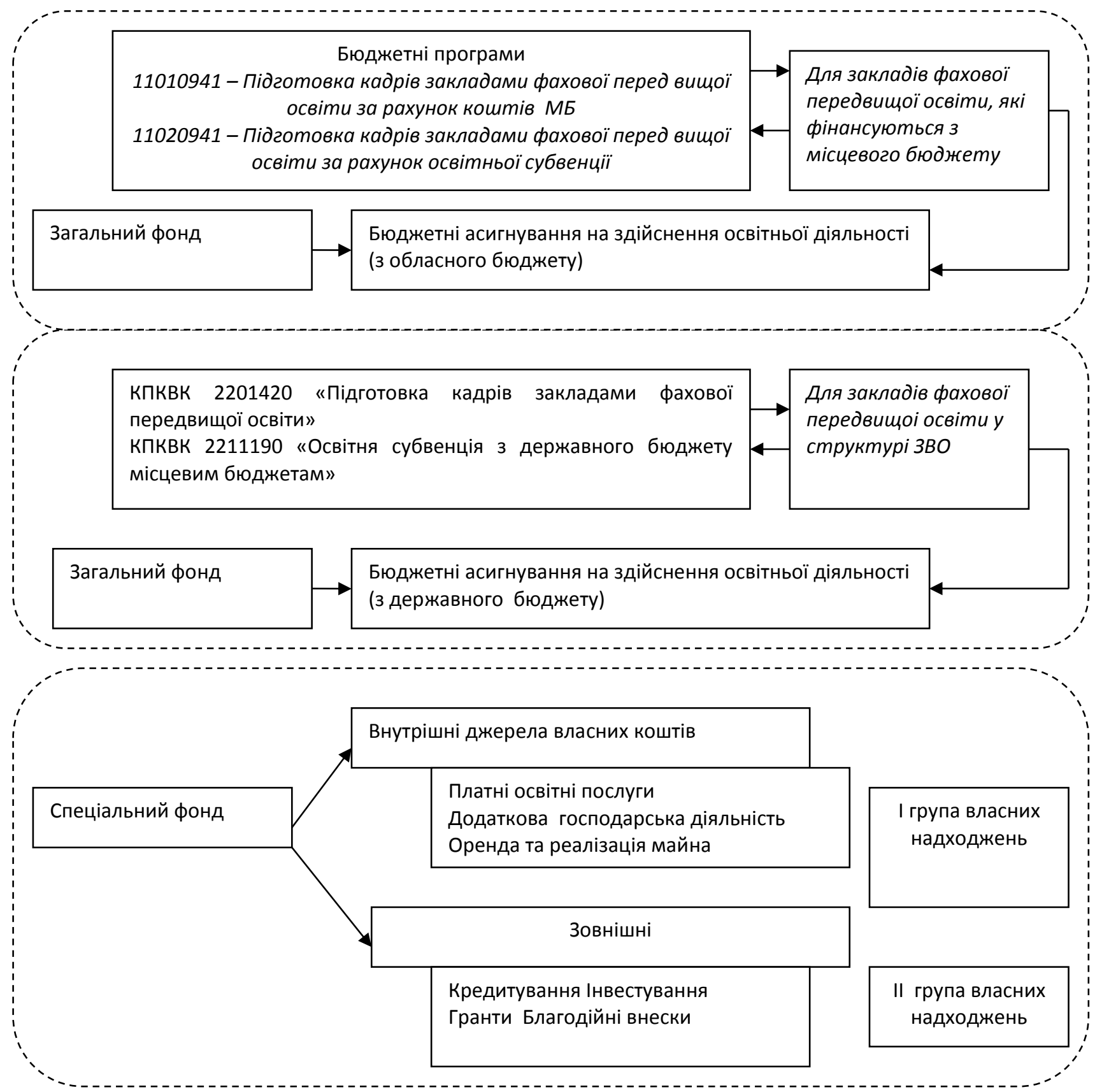

Рис. 2. Процес фінансового забезпечення закладів освіти - коледжів.

Примітка. Узагальнено автором з урахуванням чинної практики

Важливим аспектом при цьому $\epsilon$, те, що додаткові кошти не можуть бути вилучені в дохід держави або місцевих бюджетів та спрямовуються на діяльність, визначену статутом закладу освіти. При цьому витрачати кошти першої підгрупи навчальні заклади мають право лише на покриття витрат, пов'язаних з наданням послуги.

Що стосується надходжень другої групи то кошти, матеріальні та нематеріальні активи, які надходять коледжу у вигляді безповоротної фінансової допомоги, інших надходжень, добровільних пожертвувань, не вважаються прибутком, бюджетне фінансування у такому випадку не зменшується. Заклади освіти самостійно розпоряджаються надходженнями від здійснення господарської та іншої діяльності, яка передбачена Статутом.

Формування облікової політики бюджетних установ можна розглядати як напрям підвищення ефективності їх функціонування [17, с. 101]. Головною перевагою взаємозв'язку облікових політик між установами різних рівнів $€$ полегшення контролю над організаціями нижчих рівнів. Отже, формування та використання фінансових ресурсів 
www.econa.org.ua

закладів освіти суворо регламентується бюджетним законодавством, в тому числі і по власних коштах, але щодо їх обліку необхідне вирішення наявних альтернатив, дозволених обліковими регламентами. Таким чином, формування облікової політики конкретної бюджетної установи здатне вирішити ще й задачу ефективного використання бюджетних коштів за рахунок зменшення витрат на збір, обробку, надання інформації та зменшення викривлення останньої. Порядок та етапи формування облікової політики закладів фахової перед вищої освіти в, що фінансуються з обласних бюджетів систематизовано на рис. 3.

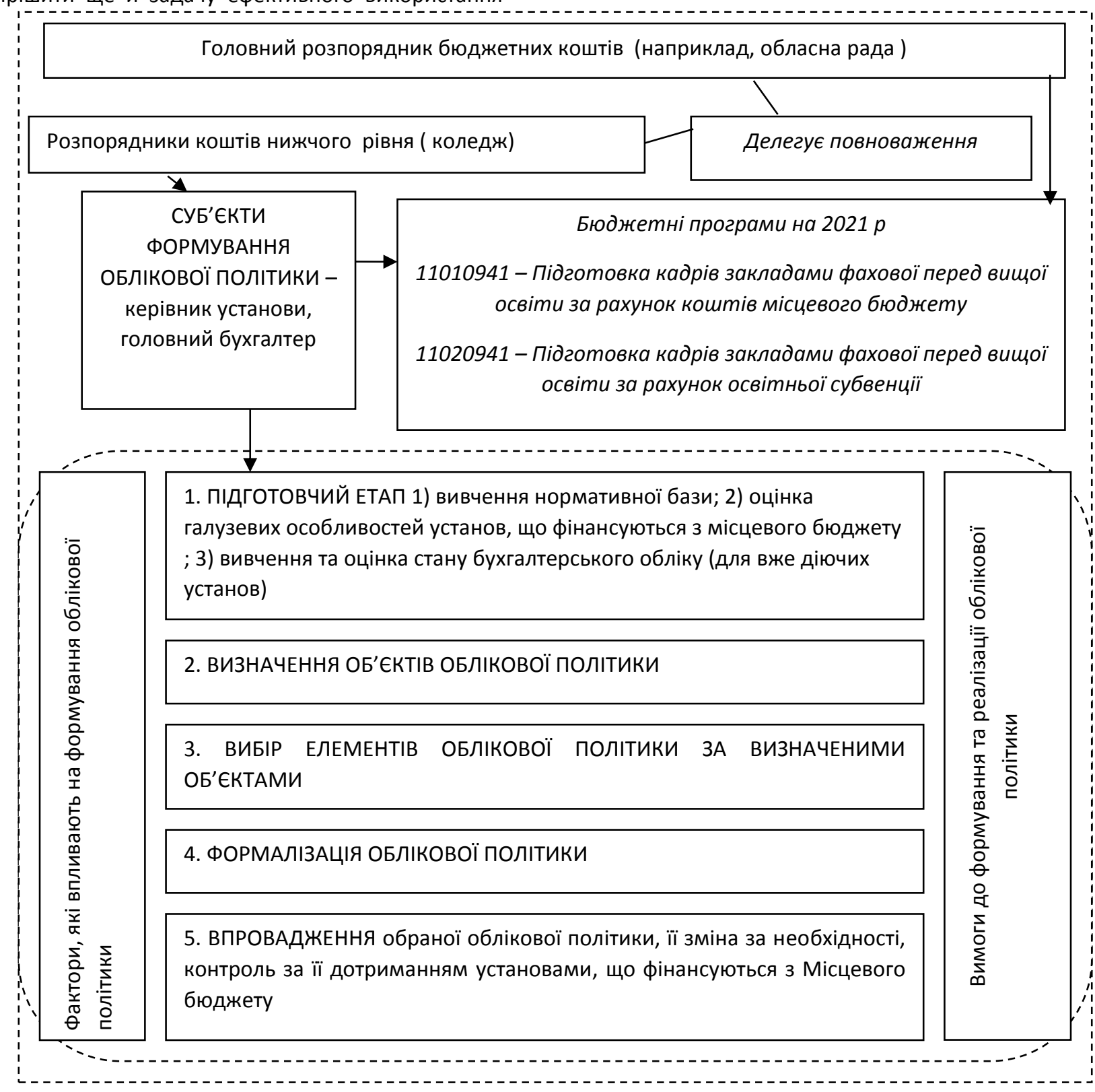

Рис. 3. Процес формування облікової політики закладу фахової перед вищої освіти, що фінансується з місцевого бюджету

Примітка. Систематизовано авторами.

3 метою уніфікації обліку в процесі формування облікової політики також доцільно:

- розробити Робочий план рахунків бухгалтерського обліку для кожної установи, яка фінансується в межах Бюджетної програми 11010941 - Підготовка кадрів закладами фахової перед вищої освіти за рахунок коштів місцевого бюджету із врахуванням додаткових аналітичних рахунків для обліку доходів за джерелами фінансового забезпечення та відповідно витрат із зазначенням усіх аналітичних рахунків щодо усіх видів діяльності, згрупувавши їх за напрямами; при формуванні елементів облікової політики щодо наявних альтернатив в обліку (методи оцінки запасів, нарахування амортизації та ін.) 
www.econa.org.ua

уніфікувати їх у межах бюджетної програми для усіх установ;

- для кожного закладу фахової передвищої окрім чинних форми фінансової та бюджетної звітності обумовити необхідність формування форм управлінської звітності, які будуть використані для проведення аналізу якості надання послуг та ефективності виконання бюджетної програми;

- 3 метою здійснення контролю та аналізу використання бюджетних коштів за бюджетною програмою доцільно формувати консолідовану звітність (за усіма закладами, що фінансуються за програмою).

\section{Висновки та перспективи подальших розвідок}

Таким чином, питання фінансового забезпечення освітніх закладів - коледжів лежить в площині двох важливих систем - бюджетної та облікової. Перша реалізується за відповідним механізмом, прописаним чинним законодавством, друга, окрім цього керується інструктивними документами і стандартами. Але в обох випадках $€$ можливості і шляхи до удосконалень. Але в будьякому разі такі удосконалення повинні забезпечувати ефективне витрачання виділених коштів і сприяти оптимізації використання бюджетних коштів загалом. I фінансовий механізм і облікова політика можуть відіграти в цьому процесі суттєву роль. Запропоновані вище удосконалення, в тому числі в частині облікової політики, стануть дієвим інструментом підвищення ефективності як самого обліку, так і використання коштів бюджету, тобто, діяльності конкретної установи або ж програми, за якою здійснюються видатки у межах повноважень. Це надасть можливість підвищити роль облікової політики бюджетної установи як елемента управління процесами господарювання, бо детально сформована, вона дає змогу керівництву аналізувати роботу установи, контролювати надходження доходів як загального так і спеціального фонду.

В перспективі такі дослідження можуть реалізовуватися шляхом вивчення позитивного зарубіжного досвіду, адже європейська орієнтація України та розвиток міжнародних зав'язків безумовно позначаються на механізмі функціонування освіти загалом, і механізму їі фінансового забезпечення та обліку, зокрема. А адаптація національного законодавства до міжнародних стандартів у питаннях облікової політики суб'єктів державного сектору $є$ вагомим результатом на даному етапі, але в наявності $\epsilon$ певні проблеми з імплементацією стандартів, з їх методичним та організаційним забезпеченням, доведенням їх положень до кожного бухгалтера бюджетної установи, налагодженням інформаційного та програмного забезпечення.

\section{СПИСОК ВИКОРИСТАНИХ ДЖЕРЕЛ}

1. Бенько І. Д. Проблемні аспекти організації обліку в установах освіти. Науковий вісник Херсонського державного університету. Сер. : Економічні науки. 2017. Вип. 24(2). С. 114-117. URL:

http://nbuv.gov.ua/UJRN/Nvkhdu_e n_2017_24\%282\%29_27.

2. Бучковська Я. Г., Баранецька О. В. Фінансування освіти в Україні: стан та перспективи. Університетські наукові записки. 2017. № 64. C. 259-271.

3. Бюджетний кодекс України: Закон України від 15.12.2020 р. №1081IX.

4. Варналій 3. С., Красільник О. В. Оптимізація фінансування державних вищих навчальних закладів України. Вісник КНУ імені Тараса Шевченка. 2017. № 5 (194). C. 6-13.

5. Варналій 3.С., Красільник О. В. Хмелевська Л. П. Фінансування державних вищих навчальних закладів України. Київ: Знання України. 2017. 231 с.
6. Глухова В. I. Фінансування видатків бюджету на вищу освіту в Україні. Ефективна економіка. $2020 . \quad$ №5. URL: http://www.economy.nayka.com.ua /?op=1\&z=7934.

DOI: 10.32702/2307-21052020.5 .98 .

7. Григанська, С.В. Фінансове забезпечення розвитку вищих навчальних закладів на державному рівні. Державне будівництво. 2007. № 2. URL: http://www.kbuapa. kharkov.ua/ebook.

8. Загірняк Д. М. Методологічні засади реновації державного фінансування закладів вищої освіти. Ефективна економіка. 2018. № $6 . \quad$ URL: http://www.economy.nayka.com.ua $/$ ?op $=1 \& z=6567$

9. Казюк Я. Фінансова децентралізація і бюджети перших 159 об'єднаних громад в деталях. Децентралізація дає можливості. $2016 . \quad$ URL: https://decentralization.gov.ua/new s/5244
10. Коваленко Я. Моніторинг та оцінка ефективності бюджетних програм як складові ресурсного циклу цОВВ. Ефективність державного управління. 2016. Вип. 4 (49). Ч.2. С.336-443.

11. Норд Г. Л., Руденко Н. О Особливості фінансування та казначейського обслуговування бюджетних установ на прикладі ВН3. Наукові праці. 2011. Вип. 149. T. 161. C. 61-66.

12. Пігуль Н. Г., Люта О. В. Особливості реалізації фінансового механізму бюджетних установ. Вісник Академії митної служби України. 2010. № 2 (44). C. 94-101.

13. Податковий кодекс України [Електронний ресурс]: Закон України №2755-VI від 02.12.2010 p. URL: http://zakon0. rada.gov.ua/laws/show/2755-17. 
www econa.org.ua

14. Полозюк К. О., Лукашова І. О. Організація управлінського обліку в бюджетних установах Донецький національний університет економіки і торгівлі імені Михайла ТуганБарановського. 2010. URL:

\section{REFERENCES}

1. Benko, I. D. (2017). Problemni aspekty orhanizatsii obliku v ustanovakh osvity [Problematic aspects of accounting in educational institutions]. Naukovyi visnyk Khersonskoho derzhavnoho universytetu. Ser. : Ekonomichn nauky, 24(2), 114-117. Retrieved from

http://nbuv.gov.ua/UJRN/Nvkhdu_e n_2017_24\%282\%29_27 [in Ukrainian].

2. Buchkovska, Ya. H., Baranetska, O. V.

Finansuvannia osvity $v$ Ukraini: stan ta perspektyvy [Financing of education in Ukraine: state and prospects]. Universytetski naukovi zapysky, 64, 259-271 [in Ukrainian].

3. Biudzhetnyi kodeks Ukrainy (2020). [Budget Code of Ukraine]: Zakon Ukrainy vid 15.12.2020 r. №1081-IX [in Ukrainian].

4. Varnalii, Z. S., \& Krasilnyk, O. V (2017). Optymizatsiia finansuvannia derzhavnykh vyshchykh navchalnykh zakladiv Ukrainy [Optimization of financing of state higher educational institutions of Ukraine]. Visnyk KNU imeni Tarasa Shevchenka, 5 (194), 6-13 [in Ukrainian].

5. Varnalii, Z. S., Krasilnyk, O. V. Khmelevska, L. P. (2017). Finansuvannia derzhavnykh vyshchykh navchalnykh zakladiv Ukrainy [Financing of state higher educational institutions of Ukraine]. Kyiv: Znannia Ukrainy. [in Ukrainian].

6. Hlukhova, V. I. (2020). Finansuvannia vydatkiv biudzhetu na vyshchu osvitu v Ukraini [Financing of budget expenditures for higher education in Ukraine] Efektyvna ekonomika, 5. Retrieved from

http://www.economy.nayka.com.ua /?op $=1 \& z=7934$ DOI: 10.32702/2307-2105-2020.5.98 [in Ukrainian].
http://www.rusnauka.com/14_NPR T 2010 /Economics/66896.doc.htm.

15. Про вищу освіту : Закон України від 1.07.2014 р. №1556-VII.

16. Про фахову передвищу освіту : Закон України від 06.06.2019 р. №2745-VIII.

7. Hryhanska, S. V. (2007). Finansove zabezpechennia rozvytku vyshchykh navchalnykh zakladiv na derzhavnomu rivni [Financial support for the development of higher education institutions at the state level]. Derzhavne budivnytstvo, 2. Retrieved from: http://www.kbuapa. kharkov.ua/ebook [in Ukrainian].

8. Zahirniak, D. M. (2018). Metodolohichni zasady renovatsii derzhavnoho finansuvannia zakladiv vyshchoi osvity [Methodological principles of renovation of state funding of higher education institutions]. Efektyvna ekonomika, 6. Retrieved from: http://www.economy.nayka.com.ua /?op=1\&z=6567 [in Ukrainian].

9. Kaziuk, Ya. (2016). Finansova detsentralizatsiia i biudzhety pershykh 159 obiednanykh hromad $v$ detaliakh [Financial decentralization and budgets of the first 159 united communities in detail]. Detsentralizatsiia daie mozhlyvosti. Retrieved from: https://decentralization.gov.ua/new s/5244 [in Ukrainian].

10. Kovalenko, Ya. (2016). Monitorynh ta otsinka efektyvnosti biudzhetnykh prohram yak skladovi resursnoho tsyklu TsOVV [Monitoring and evaluation of the effectiveness of budget programs as components of the resource cycle of central executive bodies]. Efektyvnist derzhavnoho upravlinnia, 4 (49), 336-443 [in Ukrainian]

11. Nord, H. L., \& Rudenko, N. O. (2011). Osoblyvosti finansuvannia ta kaznacheiskoho obsluhovuvannia biudzhetnykh ustanov na prykladi VNZ [Features of financing and treasury service of budgetary institutions on the example of higher educational institutions]. Naukovi pratsi, 161, 61-66 [in Ukrainian]
17. Сисюк, С.В., Адамик, О.В. Облікова політика суб'єктів державного сектору щодо необоротних активів. Вісник ОНУ імені I.I. Мечникова. 2016. Вісник 21 (11 (53)). С. $101-106$

12. Pihul, N. H., \& Liuta, O. V. (2010) Osoblyvosti realizatsii finansovoho mekhanizmu biudzhetnykh ustanov [Features of realization of the financial mechanism of budgetary institutions]. Visnyk Akademii mytnoi sluzhby Ukrainy, 2 (44), 94101 [in Ukrainian]

13. Podatkovyi kodeks Ukrainy (2010). [Tax Code of Ukraine]: Zakon Ukrainy №2755-VI vid 02.12.2010 r. Retrieved from: http://zakonOrada.gov.ua/laws/sho w/2755-17 [in Ukrainian].

14. Poloziuk, K. O., \& Lukashova, I. O. (2010). Orhanizatsiia upravlinskoho obliku v biudzhetnykh ustanovakh [Organization of management accounting in budgetary institutions]. Donetskyi natsionalnyi universytet ekonomiky $i$ torhivli imeni Mykhaila TuhanBaranovskoho. Retrieved from: http://www.rusnauka.com/14_NPR T 2010/Economics/66896.doc.htm [in Ukrainian].

15. Pro vyshchu osvitu (2021). [About higher education]: Zakon Ukrainy vid 1.07.2014 r. №1556-VII (v redaktsii 23.04.2021 r.) [in Ukrainian].

16. Pro fakhovu peredvyshchu osvitu (2021) [About professional higher education]: Zakon Ukrainy vid 06.06.2019 r. №2745-VIII (v redaktsii vid 23.04.2021 r.) [in Ukrainian].

17. Sysiuk, S. V., \& Adamyk, O. V. (2016). Oblikova polityka subiektiv derzhavnoho sektoru shchodo neoborotnykh aktyviv [Accounting policy of public sector entities for non-current assets]. Visnyk ONU imeni I.I. Mechnykova, 21 (11 (53)), 101-106 [in Ukrainian]. 